日䠦外医会誌 $53(7), 1676-1680,1992$

症例

潰瘍性大腸炎に合併した進行直腸癌の 1 例

田畑胃晹病院外科

松井祥治黒田大介張麗月田畑文平

神戸大学第 2 病理

藤 盛 孝 博

兵庫医科大学第 2 外科

石川羊男

症例恃48葴男性で体格中等度，8年前に全大腸炎型の謴場性大晹炎之䛦断されたが， 内科的治療にて数力月で軽快した。 しかしその後は大腸精査を受けずそのま放置して いたが，今回腹部膨满感と粘血便を主訴として再来院した，注腸透視と下部消化管内視

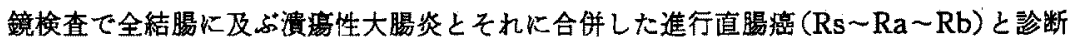
された，全結腸切除兼直晹切断術を施行し右下腹部に永久回腸灌を造設した。一且軽快 退院したものの約10カ月後に局所再発，多発性肺転移，肝転移で死亡した。

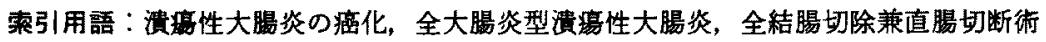

\section{精 咅}

1925年にCrohn and Rosenberg ${ }^{1}$ がはじめて遗瘍性 大陽炎に大腸㴽を合併した症例を報告し，1928年 Bargen²が同様な症例を17例報告して以来溃痬性大腸 炎に癌が高率に合併する事は広く知られている。しか し日本では欧米諸国に比して癌化例の報告は末だ少な く50例に渵たない3).今回私達は 8 年前に全大陽次型 の瀆燷性大腸炎で内科的治㞠を受け軽快した後十分な surveillance を受けず 8 年啳に進行直腸癌を合併して 来院した1例を経験したので文献的考察を加えて報告 した.

$$
\text { 症例 }
$$

患者：48藏，男性.

主訴：腹部膨満感，粘血便.

現病歷：約 8 年前に全大腸炎型の潰晹性大腸炎で内 科的治療を受け数カ月で軽快しその後は全く follow upを受けず的 2 年前に便秘等の症状で当科を訲れ精 査の予䄪をするも来院せずそのまま之なっていた，今 回腹部膨満感と粘血便を訴えて来院し注腸透視，下部 消化管内視鏡検査，生検の結果潰湯性大腸炎に合併し た進行直腸癌の診断で入院となった。

既往歴：約13年前に十二指腸溃瘍で胃切除術を受け

1991年10月 4日受付 1992年 4 月16日採用
た. Billroth II 法, 結晹前で再建.

現症：身長 $164 \mathrm{~cm}$ ，体重62kg で中肉中背. 腹部はゃ

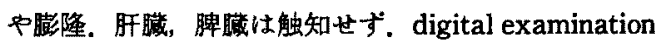
で直腸下部に全周性の弾性硬な睡瘤を触知した，また 睡瘤は易出血性であった。

血液検查所見：一般血液検査，生化学検查では異常 值は見られなかったが CEA は110.5mg/dl と異常高 値を示していた（表1）。

注腸透視所見：回盲部からS 状結腸にかけて haustraの消失と腸管の短䑿を認め正常粘膜パターソは消

\section{表 1 入院時一般挨查成綪}

\begin{tabular}{lcll}
\hline WBC & $5700 / \mathrm{mm}^{3}$ & TP & $7.1 \mathrm{~g} / \mathrm{d} \ell$ \\
RBC & $436 \times 10^{4} / \mathrm{mm}^{3}$ & GOT & $24 \mathrm{U}$ \\
$\mathrm{Hb}$ & $11.2 \mathrm{~g} / \mathrm{d \ell}$ & GPT & $24 \mathrm{U}$ \\
$\mathrm{Ht}$ & $34.4 \%$ & T-Bil & $0.3 \mathrm{mg} / \mathrm{d} \ell$ \\
& & Y-GTP & $16 \mathrm{mu} / \mathrm{m \ell}$ \\
CEA & $110.5 \mathrm{ng} / \mathrm{m \ell}$ & ALP & $4.6 \mathrm{KA}$ \\
フェリチン & $192 \mathrm{ng} / \mathrm{m \ell}$ & LDH & $276 \mathrm{U}$ \\
& & Na & $134 \mathrm{mEq} / \ell$ \\
& & Cl & $102 \mathrm{mEq} / \ell$ \\
& & $\mathrm{K}$ & $3.8 \mathrm{mEq} / \ell$ \\
& & BS & $93 \mathrm{mg} / \mathrm{d} \ell$ \\
\hline
\end{tabular}




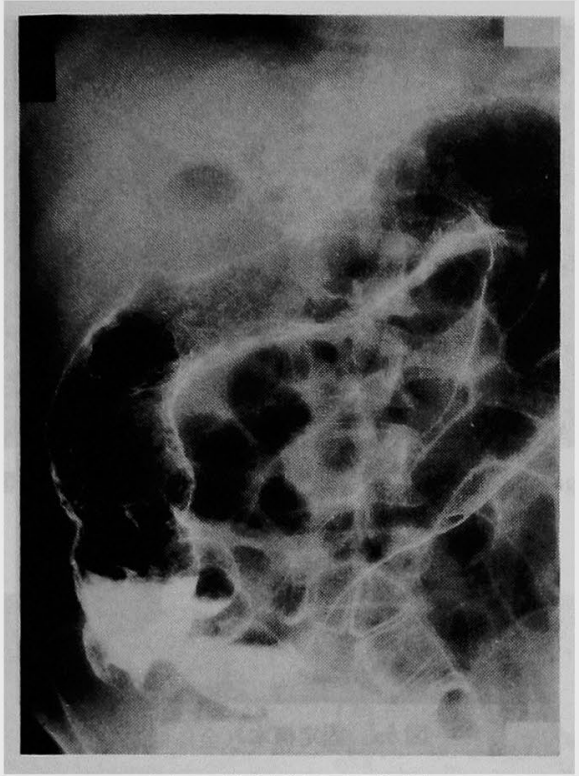

図 1 注腸透視（全体像）

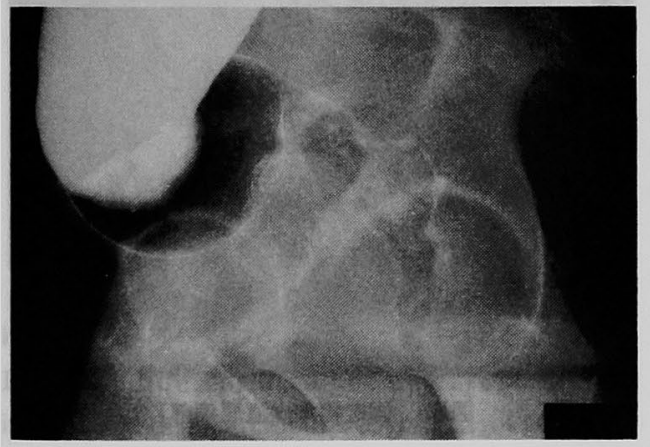

图2 注堿透視（直腸癌部）

失しいわゆる鉛管状を呈していた，直腸全域 $(\mathrm{Rs} \sim \mathrm{Ra}$ ～Rb）一部肛門管にす及よ゙長さ約 $12 \mathrm{~cm}$ の高度な㹟窄 像が見られた（図1，図2）。

下部消化管内視鏡所見：直腸には白苔を有する易出 血性の巨大な全周性の潰湯が見られるが口側，肛側と もに周堤ははっきりしなかった．Ｓ状結腸部に㾿痕化 した縦走溃湯が見られ結腸全般の粘膜面は粗造で易出 血性であった。生険では直腸より signet ring cell carcinoma が出た（図 3)。

CT 所見：直腸の全周性の腫瘤と後方より仙骨面に 向けて間吵の脂肪織への漫潤が見られた（図4）.

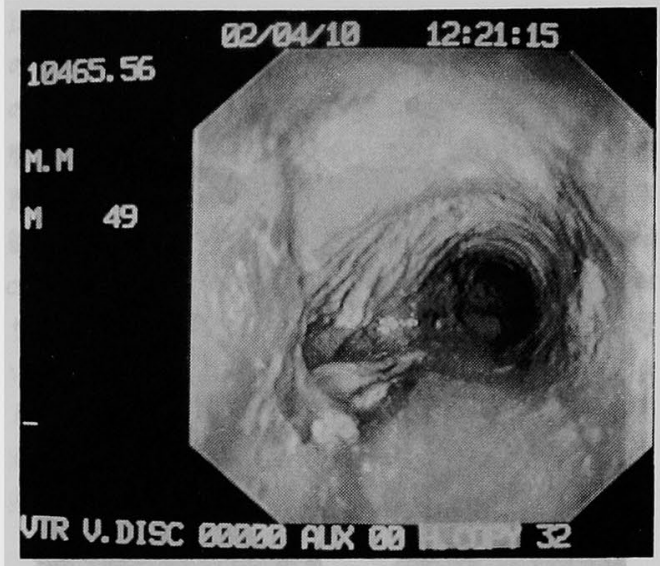

図 3 下部消化管内視鏡

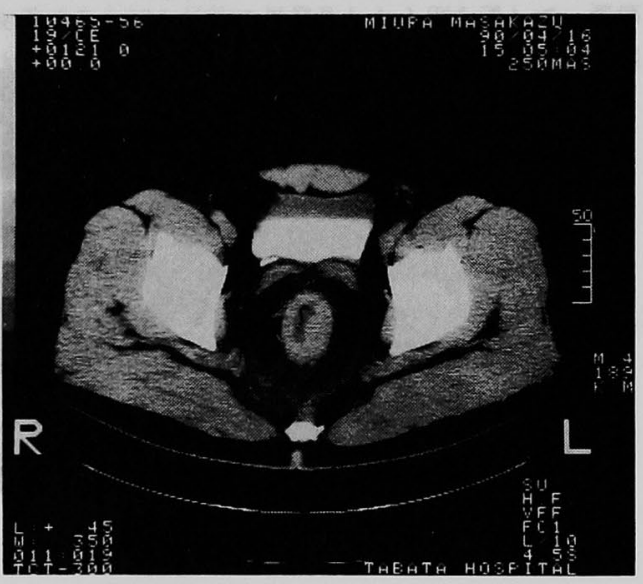

图4 CT

手術所見：体位は砕石位とし胸骨剣状突起下端から 耽骨上縁にいたる長い正中切開にて開腹した，腹腔内

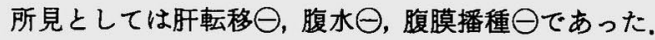
全結腸切除兼直腸切断術を施行し，右下腹部に永久回 腸戝を造設した。

切除標本：結腸全般に著明な短縮が見られ，回盲部 一上行結腸一横行結腸右半部の粘膜は糜爛, 出血が著

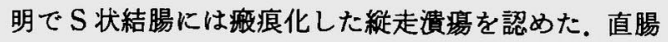
癌部は全周性の狭窄を呈しており周辺脂肪組織への浸 潤が著明で一部肛門皮庙下にまで達していた（図 5a, b, 図 6a,b).

組織所見：図 7aは直腸癌部の組織で signet ring cell が多数見られる.図7b は潰瘍性大腸炎部の組織で 


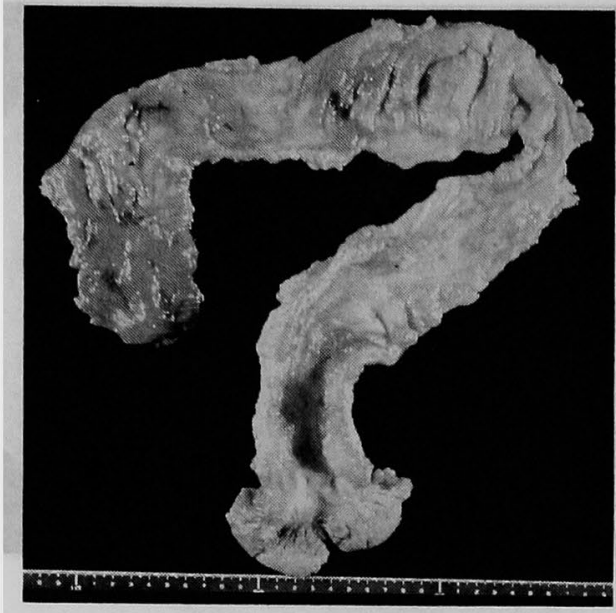

图 $5 \mathrm{a}$ 新鲜切除償本（全体像）

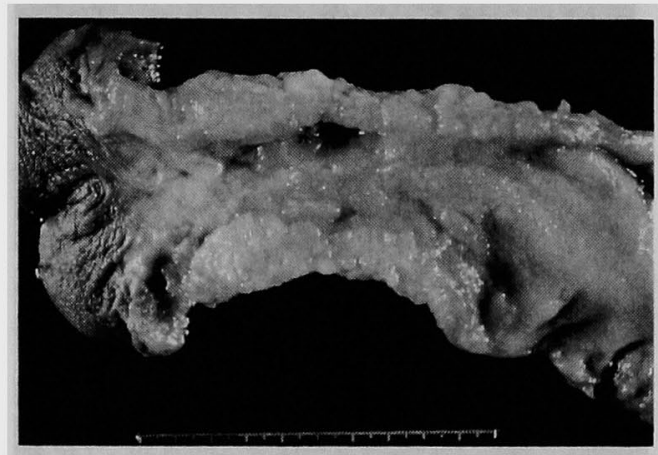

图 5b 新鲜切除标本（直腸癌部）

粘膜筋板の破壊と资症細胞の漫潤が見られる、本症例 では非癌部の潰瘍性大腸炎には前癌病変と言われる dysplasia の所見は見られなかった（図7a， b）.

\section{考案}

潰埸性大腸炎に大腸癌を合併する率は欧米では 0.6〜14\%と報告によってかなりの開きがみられるい5 が現在では $3 \%$ 前後と報告する文献が多い様である。 Dobbins $^{6)}$ の集計によれば約3.6\%で全大腸炎型と左側 大腸炎型に分けると前者は $6.3 \%$ ，後者は $1.0 \%$ となる. 本邦では1987年の時点で報告された確実な癌合併症例 はいまだに42例に過ぎず3，欧米に比して極めて少な いのが現状で合併率について言える段階ではない，潰 瘍性大腸炎に癌を合併しやすい条件として，(110年以 上の長期経過例，(2)全大腸炎型である事が一般にあげ られている5)（1)に関してはその経過が長期化すれば

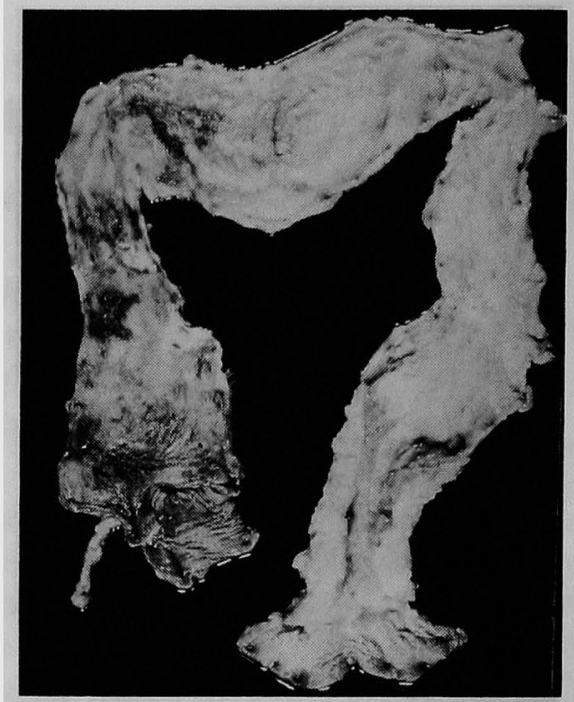

図 6a 固定㗚本（全体像）

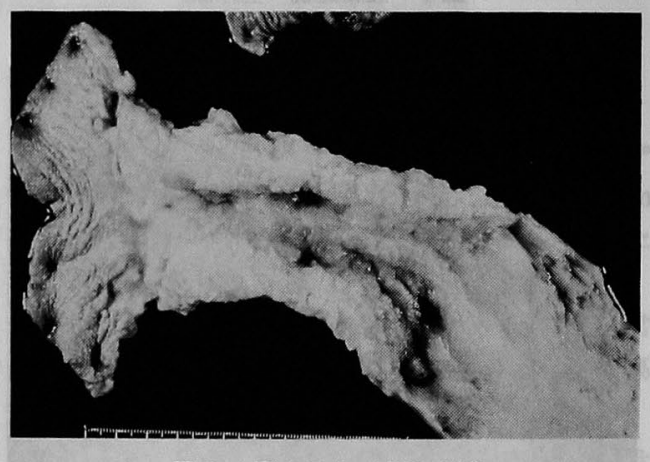

图 6b 固定标本（直腸癌部）

する程, 癌合併率は急激な増加を示すと言われてい $ろ^{537}$. (2)に関しては左側大腸炎型にも癌合併の riskは あるが全大腸资型よりかなり低いと言われている。そ の他の risk として慢性持続型が再燃緩解型よりも有

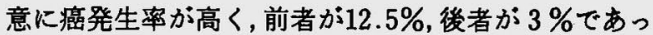
たといら報告らもみられる，本例では全大腸炎型で初 回来院してから約 8 年後進行直腸癌を合併した症例で あるので経過としては10年以下ということになるがそ の間に一度外来を訪れただけであるので恐らく慢性持 続型であったと推察される。癌の特徵として Morson ら 境界が不鮮明なるのが多い事，(3)低分化型腺癌，粘液 産生癌の頻度が通常の大腸癌より高い事（38\%）をあ 


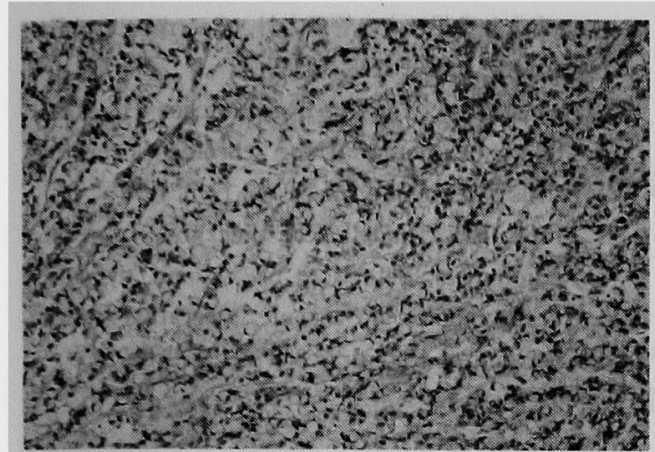

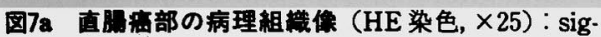
net ring cell が多数みられる.

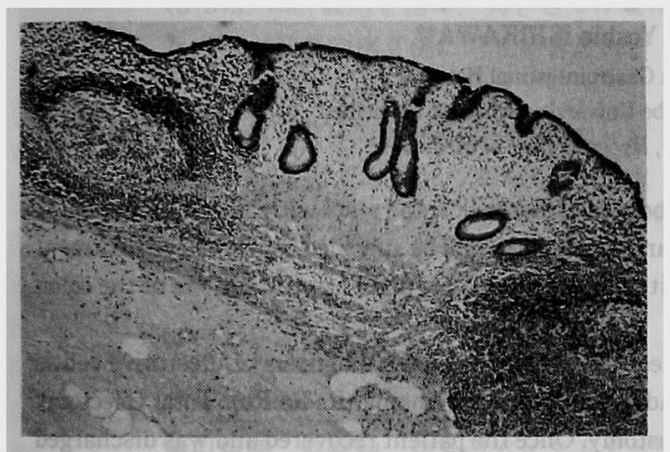

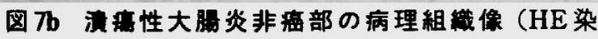
色, $\times 10$ )

げている. 病理学的な特徽として Goldgraber ら゙は, 1) well differentiated adenocarcinoma, 2) infiltrating adenocarcinoma, 3) mucinous adenocarcinoma の順に頻度が高く一般の大腸癌に比較的稀と される linitis plastica typeの病変を形成していた signet ring cell carcinoma が33例中 4 例にも認めら れたとしている。

本邦での1987年までの42例の報告例》の中です signet ring cell carcinomaは6例にみられ決して稀では ない，本症例も単発であったが，周曲との境界が不鮮 明な Borrman 4 型の直腸癌で組織型も signet ring cell carcinoma であった，癌を合併した場合の一般的 な治療は全結腸切除術であるが，本症例では直腸に発 生したので直腸切断術る合わせて行われた，潰癔性大 腸炎に合併した癌の予後について以前は一般の大腸癌 に比して不良とする説が多かったが，最近では治癁切 除が行われた場合の stage 別の予後は一般の大腸癌に
比して差がないと言われている゚10).とはいえ本症例 のごとく来院時進行癌となっている症例も少なくない ので，溃瘍性大腸炎に合併する癌の早期発見，早期治 療のために特に high risk 群に対して surveillance の 重要性が唱えられている(1)12). Nugent $ら^{(3)}$ は発症 5 年 後から年 1 回の直腸鏡生検と, 2 年に 1 回の total colon fiber による観察と生検を行う事を勧奖してお り，Frank ら ${ }^{14)}$ はまず 2 重造影による注腸透視を行 い，疑わしい部位を標的として内視鏡下に生検を行う 方法を勧めている，武藤ら31は経過 7 年目位から年 1 回の total colon fiber と $10 \mathrm{~cm}$ 間隔の biopsy を行うと 述ぺている。

\section{結語}

全大腸炎型の溃瘍性大腸炎の診断を受けた 8 年後に 進行直腸癌を合併して来院, 全結腸切除兼直腸切断術 を受けるす10カ月後に再発死した 1 例を通して，潰瘍 性大腸资 high risk 群の surveillance の重要性が痛感 されたので報告した。

\section{文献}

1) Crohn BB, Rosengerg H : Sigmoidoscopic picture of chronic ulcerative colitis (non specific). Am J Med Sci 170 : 220 - 228, 1925

2) Bargen JA : Chronic ulcerative colitis associated with malignant disease. Arch Surg 17 : $561-576,1928$

3）武藤徹一郎, 阿川千一郎, 大矢正俊他：溃瘍性大腸 炎と癌，消外 $10: 1976-1803,1987$

4) Goldgraber MB, Kirsner JB: Carcinoma of the colon in ulcerative colitis. Cancer 17:657 $-665,1964$

5) Edwards FC, Truelove SC: The course and prognosis of ulcerative colitis. Gut $5: 1-22$, 1964

6) Dobbins WO: Dysplasia and malignancy in inflammatory bowel disease. Ann Rev Med 35 : 33-48, 1984

7) Greenstein AJ, Sachar DB, Smith $\mathrm{H}$, et al : Cancer in universal and left-sided ulcerative colitis : Factors determining risk. Gastroenterology 77 : 290-249, 1979

8) Morson BC, Dawson IMP: Gastrointestinal Pathology. 2nd ed, Blackwell Scientific Pablications, Oxford, p534-542, 1979

9) Gyde SN, Thompson H, Waterhouse JAH, et al: Survival patients with colorectal cancer 
complicating ulcerative colitis. Gut $21: 228$ $-231,1984$

10) Ohman $U$ : Colorectal carcinoma in patients with ulcerative colitis. Am J Surg 144: 344 $-349,1982$

11) Riddell $\mathrm{RH}$, Morson $\mathrm{BC}$ : Value of sigmoids copy and biopsy in detection of carcinoma and premalignant change in ulcerative colitis. Gut $20: 575-580,1979$

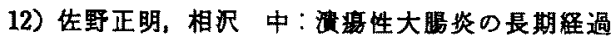

一癌化を予想しての管理方針, Gastroenterol Endosc $27: 2185-2188,1985$

13) Nugent FW, Haggitt RC, Colcher $H$, et al: Malignant potential of chronic ulcerative colitis. Gastroenterology $76: 1-5,1979$

14) Frank PH, Riddell RH, Feczko PJ, et al: Radiological detection of colonic dysplasis (precarcinoma) in chronic ulcerative colitis. Gastrointest Radiol 3 : 209-219, 1978

\title{
A CASE OF ADVANCED RECTAL CANCER WITH DDIOPATHIC ULCERATIVE COLITIS
}

\author{
Shoji MATSUI, Daisuke KURODA, Reigetsu CHO, Bunpei TABATA, \\ Takahiro FUIIMORI* and Yoshio ISHIKAWA** \\ Department of Surgery, Tabata Gastrointestinal Hospital \\ * Second Department of Pathology. Kobe University School of Medicine \\ **Second Department of Surgery, Hyogo College of Medicine
}

A 48-year-old man was seen at the hospital because of abdominal distension and stool with blood mucus. There was a history of ulcerative colitis which was diagnosed 8 years before and could be subsided conservative treatment for several months. The patient had been left the lesion without receiving any further examinations of the colon thereafter.

On this admission barium enema and lower gastrointestinal series revealed a diagnosis of ulcerative colitis extending over the entire colon with an association of an advanced rectal carcinoma (Rs-Ra-Rb). Total colectomy with excision of the rectum was performed, followed by ileostomy. Once the patient recovered and was discharged from the hospital, however, about 10 months later, local recurrence developed. He died of multiple lung and liver metastases. 